\title{
Vliv vnímání budoucnosti na budoucnost
}

\author{
Jan Labohý, Bohuslav Binka
}

Envigogika 2013/VIII/1- Recenzované články/ Reviewed Papers

Publikováno/Published 31 05. 2013

DOI: http://dx.doi.org/10.14712/18023061.229

\begin{abstract}
Abstrakt
Na základě informací o vzrůstajícím negativismu ve společnosti si článek klade za cíl popsat, jaký dopad může mít sdílené vnímání budoucnosti na budoucnost samotnou. Prostor je věnován popisu konceptů Thomasova teorému, sebenaplňujícího se proroctví, placebo efektu a Oidipovského efektu. Ve spojitosti s nimi je zmíněn Lyotardův koncept metanarací jako "velkých vyprávění", pomáhajících na základě sdílené vize budoucnosti legitimizovat nastavení společenských institucí. Článek si klade otázku, zda existuje vztah mezi současnou krizí institucí a vzrưstajícím negativismem společnosti. Na základě aplikace výše zmíněných konceptů článek předkládá tezi, že existence sdílené pozitivní vize budoucnosti může znamenat důležitý prvek pro možnost dalšího pozitivního rozvoje současné společnosti.
\end{abstract}

\section{Klíčová slova}

Budoucnost, Thomasův teorém, placebo efekt, sebenaplňující se proroctví, oidipovský efekt, metanarace

\section{Keywords}

Future, Thomas theorem, placebo effect, self-fulfilling prophecy, oedipus effect, metanarratives 
V jednom ze svých slavných citátů francouzský básník a esejista Paul Valéry (2000) s povzdechem konstatuje, že: "budoucnost už není co bývala." Upozorňuje tím na zajímavý fenomén negativní percepce budoucnosti.

Dle průzkumu Eurobarometeru, který byl publikován v dubnu 2012, se $52 \%$ Evropanů domnívá, že v roce 2030 bude život těžší než dnes. V souvislosti s tím $63 \%$ lidí předpokládá, že dnešní děti čeká složitější život, než jaký vede současná generace ${ }^{1}$ (viz Graf 1 a Graf 2). Od roku 2009, kdy se odehrál výzkum s podobným tématem, tak dochází $\mathrm{k}$ posunu směrem $\mathrm{k}$ negativnějšímu vnímání budoucnosti.

Otázkou, odkud se tento postoj bere, a co vede současnou společnost $\mathrm{k}$ negativnímu postoji $\mathrm{k}$ budoucnosti, se však $\mathrm{v}$ rámci tohoto článku zabývat nebudu. Zaměřím se na druhou dimenzi tohoto postoje. Cílem tohoto článku bude popsat, jaký dopad může mít vnímání budoucnosti na budoucnost samotnou.

Abych lépe nastínil důležitost společenského vnímání budoucnosti, budu se $v$ následujíć ćásti věnovat vybraným teoretickým konceptům, které jsou pro tuto oblast dle mého názoru relevantní. Jedná se o Thomasưv teorém, koncept sebenaplňujícího se proroctví, Oidipovský efekt a koncept metanarací.

\section{Thomasův teorém}

Jedním ze základů moderních sociálních věd je tzv. Thomasův teorém, který pochází od amerického sociologa W. I. Thomase. Ten jej formuloval jako tezi, že: "pokud definujeme situaci jako reálnou, je reálná ve svých dopadech." (dle Merton 1948: 173) Poukázal tak na skutečnost, že lidé obecně nereagují primárně na objektivní realitu. Při svých rozhodováních reagují spíše na realitu subjektivní ${ }^{2}$, tedy na to, jaký má pro ně situace, v které se nalézají, osobní význam.

Za klasický př́klad Thomasova teorému můžeme považovat situaci nervózního studenta, který uvádí Merton (1948). Student, který si myslí, že nezvládne zkoušku, na kterou právě přichází, se díky svému přesvědčení stává nervózním. Tím snižuje svůj mentální výkon a zároveň i šanci na to, zkoušku úspěšně absolvovat. Jiné psychologické pokusy ukazují, že pokud se ve školní třídě náhodně určí několik žáků a jejich učiteli se řekne, že jsou nadprůměrně nadaní, budou mít tito žáci na konci školního roku nadprůměrné výsledky. Stane se tak díky př́stupu a jinému chování pedagoga, který očekává větší talent a proto věnuje žákům větší péči (Rosenthal a Jacobson 1968). Ačkoliv tedy vybraní žáci ve skutečnosti nebyli více nadaní než jejich spolužáci (objektivní realita), vnímání učitele (subjektivní realita) způsobilo, že se informace stala reálnou ve svých důsledcích.

Princip, ve kterém má nepravdivá informace reálné důsledky, je známý také z medicíny. Projevuje se zde jako tzv. placebo efekt. Jak popisuje Biggs (2009), mnoho výzkumů $v$ oblasti bolesti, deprese a úzkosti dokládá, že i při podání placeba namísto účinné látky dochází u pacientù k subjektivnímu vnímání pozitivní změny.

1 Podobný pocit z budoucnosti přitom člověku může přinášet také současná populární kultura, zejména filmová. Ta dle mého vnímání zobrazuje od konce 90 . let 20. století budoucnost prakticky pouze jako katastrofickou či post-apokalyptickou. At’ se jedná o klasické filmy tipu Planeta opic, Blade Runner, Den poté či v loňském roce populární film Hunger Games. Pozitivní budoucnost jako by byla nepředstavitelná nebo nezajímavá.

2 Bohužel prostor článku neumožňuje více rozvinout definice objektivní a subjektivní reality. Více se k tomuto tématu vyjadřují např. Berger a Luckmann (1999). 
QA3. Generally speaking, do you think that the life of those who are children today will be easier, more difficult or neither easier nor more difficult than the life of those from your own generation?

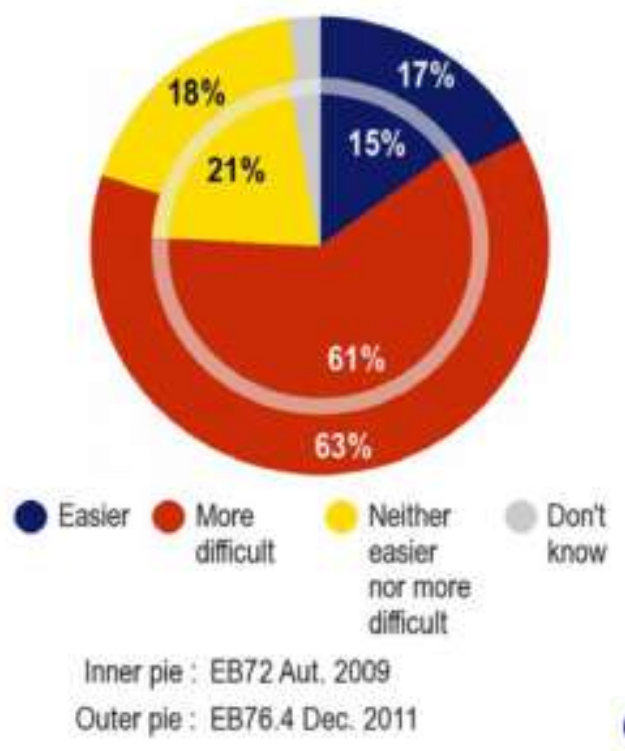

Graf 1: Jaký bude život přiští generace.
QA4. Imagine how the EU will be in 2030. Compared with today, will the life of European citizens be...?

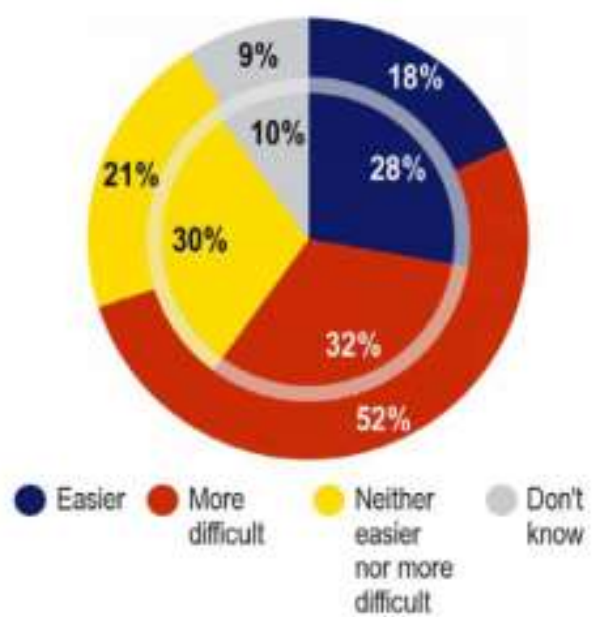

Inner pie: EB71 Sp, 2009

Outer pie : EB76.4 Dec. 2011

Graf 2: Život Evropanů v roce 2030

Zdroj: Evropská komise, 2012

\section{Sebenaplňující se proroctví}

Podobný princip nefunguje pouze na úrovni jednotlivce, jeho paralela se dá najít i na celospolečenské úrovni. Nacházíme jej v konceptu sebenaplňujícího proroctví, který poprvé popsal Robert Merton (1948). Sebenaplňující se proroctví můžeme chápat jako společenskou aplikaci Thomasova teorému.

Příkladem, který uvádí Merton (1948), je případ krachu americké Last National Bank z roku 1932. Nepravdivá zvěst o krizi likvidity této banky, která se začala šiŕit společností, způsobila, že lidé začali spěšně vybírat prostředky, které měli $v$ bance uložené. Tím způsobili bance skutečnou krizi likvidity, která vedla až k pádu celé Last National Bank. Přesvědčení o krizi likvidity tak způsobilo, že tato krize doopravdy nastala.

Merton tento princip zobecňuje a říká, že: „Vnímání situace veřejností (předpovědi či proroctví) se stává integrální součástí situace a tím ovlivňují její následný vývoj." (Merton 1948: 175). Jako príklad uvádí situaci, $v$ níž je obyvatelstvo dvou států presvědčeno, že vojenský konflikt mezi jejich státy je nevyhnutelný. Pakliže bude toto přesvědčení sdílet většina populace, povede to ke změně ve vzorcích interpretace reality. Vzájemné chování států bude častěji vnímáno jako provokace, vojenské přípravy, vyzbrojování a plánování potenciálního konfliktu, což povede $\mathrm{k}$ tomu, že válka bude do budoucna mnohem pravděpodobnější alternativou. Merton tedy sebenaplňující se proroctví chápe jako 
nepravdivé vnímání situace, které podporuje takové chování, které způsobí, že se původní nepravdivé vnímání stane skutečností3

O podobném principu pak mluví i Popper (1957: 11), když definuje tzv. Oidipovskýy efekt ${ }^{5}$ jako vliv předpovědi na předvídanou událost. Již tím, že pronášíme predikci, působíme na pravděpodobnost jejího naplnění. Tento vliv může být pozitivní (podporuje, že se událost stane) nebo negativní (brání $v$ tom, aby nastala). ${ }^{6}$ Obecněji pak můžeme oidipovský efekt definovat jako vliv informace na situaci, ke které se tato informace vztahuje.

\section{Různé předpovědi tvoří různé reality}

Pokud přijmeme tezi, se kterou přichází Berger a Luckmann (1999), že sociální realita není objektivně dána, ale je neustále znovu konstruována, můžeme vyvodit, že různá vnímání budoucnosti (proroctví či vize) budou na základě principu sociálního konstruktivismu vytvářet různé reality. To by dle mého názoru mohlo znamenat, že je možné princip Oidipovského efektu abstrahovat na vyšší úroveň.

Zatímco Thomasův teorém a sebenaplňující se proroctví se primárně vztahují k jednotlivým a konkrétním událostem a jejich předpovědím, domnívám se, že by jejich vnitřní princip mohl fungovat i obecněji. Tedy, že samotná povaha očekávání může tím, jak vytváří specifickou realitu, ovlivňovat povahu budoucnosti. Pokud bychom tento princip aplikovali na celospolečenskou úroveň, znamenalo by to, že kolektivní společenská očekávání ovlivňují celkové směřování společnosti. Tedy, že negativní smýšlení o budoucnosti může činit takovouto alternativu pravděpodobnější, zatímco optimistický výhled může působit podobně jako placebo a zvyšovat pravděpodobnost pozitivnějšího vývoje.

\section{Metanarace}

Co si ale můžeme představit pod spojením kolektivní společenské očekávání? Pro jeho popsání bych si rád vypůjčil Lyotardův pojem metanarace neboli "velké vyprávění (Lyotard 1993). Metanarace mưžeme chápat jako metaforická sdílená chápání současnosti na základě shodné interpretace minulosti a společné vize budoucnosti. Metanarace tak $v$ lyotardovském pojetí pomáhají konstruovat realitu své doby a jsou základní charakteristikou společně vnímaného směřování společnosti?

3 Jak ale dodává Merton, je třeba rozlišovat, $v$ jakých kategoriích se proroctví pohybuje. Předpovědi návratu Halleyovy komety evidentně neovlivní její oběžnou dráhu, pohybujeme se vždy v oblasti sociální reality.

$4 \quad$ Popper přitom vychází z př́iběhu o Oidipovi, ve kterém věštba hraje roli spouštěče událostí, které vedou k jejímu naplnění.

$5 \quad$ Oidipovský efekt je rozdílný od Oidipovského komplexu, který se v psychoanalýze používá společně s Elektřiným komplexem jako označení erotického vztahu dítěte k rodiči opačného pohlaví.

$6 \quad$ V podstatě se jedná o mechanismus pozitivní a negativní zpětné vazby.

7 Jako př́íklad metanarace můžeme použít osvícenskou ideu pokroku. Ta chápe dějiny jako cestu k racionálnímu jedinci a budoucnost jako vědeckou aplikaci racionality, která povede k popsání a pochopení světového řádu. 
Podle Lyotarda je důležitou charakteristikou metanarací jejich všeobecné uznávání a porozumění. Díky tomu pak metanarace slouží k legitimizaci určitého způsobu fungování kultury a $\mathrm{k}$ interpretaci a obhajobě sociálního dění v jejím rámci. Lyotard přímo říká, že: "(Metanarace)...mají zajisté tak jako mýty za účel legitimizovat společenské a politické instituce a praktiky, ustavení zákonů, různé etiky a způsoby myšlení. Ale na rozdíl od mýtů nehledají tuto legitimitu $v$ nějakém prapůvodním zakládajícím činu, nýbrž v budoucnosti, jejiž př́chod se má připravit, to znamená v určité Ideji, která má být realizována." (Lyotard 1993: 29)

Pro účely tohoto článku tedy budeme metanaraci chápat jako způsob, jak nahlížet na obecně sdílené vědomí o budoucnosti (předpovědi). ${ }^{8}$

\section{Konec velkých vyprávění}

Zatímco v minulosti byly jednotlivé společnosti dle Lyotarda definovány existencí své metanarace, současná postmoderní společnost je specifická právě její absencí. Postmoderna pro Lyotarda znamená "konec velkých vyprávění" (Lyotard 1993). Společnost ztrácí společnou jednotící vizi, což $v$ důsledku vede ke krizi legitimity, nebot' nastavení společnosti a jejích institucí ztrácí své opodstatnění. Společnost se tak logicky dostává do krize, nebot́ nepř́tomnost metanarace přestává držet společnost pohromadě9.

O podobné charakteristice dnešní společnosti mluví i Funda (2000), když podotýká, že: "Civilizace zaniká tehdy, když ztratila vizi. Antika měla své vize, křestáanská Evropa měla své vize, osvícenství mělo své vize, sekulární humanismus měl své vize, průmyslová revoluce měla své vize. Má naše Evropa - usilující pod hrozbou převahy severoamerického a východoasijského ekonomického potenciálu o sjednocení - ještě nějakou vizi? Myslím, že ne. Pouhé stoupání konzumního ekonomického blahobytu, ignorujícího hranice růstu, nemůže být a snad ani nechce být vizí. Ovšem výrobní, tržní a přepravní mechanismy budou fungovat i bez vize. Civilizace může fungovat jako stroj bez cítění a bez myšlení. Je to však fungování $\mathrm{k}$ smrti. Žádná ze stávajících civilizací $\mathrm{v}$ dějinách takové fungování mechanismů bez vize nepřežila." (Funda 2000: 136)

Princip rozkladu společnosti popisují i Giddens (2003) a Beck (2004), když definují současnost jako reflexivní modernitu. Tedy jako dobu, kdy společnost musí reagovat na krizi vlastních institucí, která pramení z jejich samotné podstaty. Stejně, jako modernita rozkládala instituce tradiční společnosti, rozkládá reflexivní modernita instituce společnosti moderní.

Ocitáme se tedy $v$ situaci, kdy vidíme rozklad institucí a legitimity současné společnosti. Zároveň sledujeme stoupající negativismus ve spojitosti s očekáváními budoucnosti. Je otázkou, zda spolu tyto dva trendy souvisí.

Důležitým momentem této debaty je otázka, jestli je skutečně dnešní společnost charakterizována nedůvěrou vưči metanaracím, jak si myslí Lyotard, nebo se nachází

8 Je však důležité si uvědomit, že oproti sociologickým konceptům Thomasova teorému a sebenaplňujícího proroctví jsou lyotardovské metanarace pouhou pomůckou k analýze současnosti. Nejedná se o vědecky ověřovaná sociologická fakta, nýbrž o filozofickou možnost náhledu na skutečnost. Jde o způsob, jak společnost z určitého úhlu charakterizovat, přičemž tento úhel pohledu není společnosti vlastní.

9 Paralelu k tomuto principu můžeme najít i v Bibli, která v kapitole přísloví ŕíká: „Kde není vize, lidé zahynou. "(Bible, Př́sloví 29: 18) 
ve stádiu přechodu, kdy může docházet k zrodu nových institucí i nové metanarace, která určí další směřování společnosti ${ }^{10}$.

\section{Závěr}

V době, kdy průzkum Eurobarometru naznačuje v Evropě postupující nárůst negativního vnímání budoucnosti, je dle mého názoru důležité zkoumat, jaký může mít tento proces skutečný dopad na budoucnost.

Vrat'me se $v$ tuto chvíli zpět a odpovězme si na otázku stanovenou na začátku článku - jakým způsobem může ovlivňovat současná vize budoucnosti budoucnost samotnou? Na základě výše popsaného se domnívám, že negativní vnímání budoucnosti má v sobě potenciál činit takovouto budoucnost pravděpodobnější. Ne ale nevyhnutelně.

O možnosti narušit sebenaplňující se proroctví hovoří i Merton. Začarovaný kruh je podle něj možné narušit za předpokladu, že je původní domněnka nahrazena jinou. „Pouze pokud je pưvodní předpoklad zpochybněn a místo něj nastoupí jiné vnímání situace, může sled následných událostí pưvodní domněnku vyvrátit." (Merton 1948: 177)

Současně se domnívám, že pozitivní vnímání budoucnosti může napomáhat realizaci této vize. I v současné debatě přitom můžeme narazit na proudy, které mohou tento názor podpořit. Jako příklad můžeme použít organizaci Transition Towns ${ }^{11}$, která používá následující motto:, „Pokud si nedovedeme představit pozitivní budoucnost, nebudeme schopni ji vytvořit" (Transition Towns, 2012).

Pokud by měla existovat takováto vize a měla by být společností akceptovatelná, jedná se svým způsobem o novou metanaraci. Jak bylo popsáno výše, šlo by o nový princip interpretace minulosti a novou společnou vizi budoucnosti. Otázkou, kterou ponechávám na závěr článku, je, kde bychom mohli takovouto vizi v dnešní době nalézt.

Tento článek vznikl $v$ rámci projektu Environmentální aspekty životního způsobu III (MUNI/A/0788/2011) Masarykovy Univerzity. Děkujeme!

\section{Literatura}

- Beck, U. (2004). Riziková společnost: Na cestě k jiné moderně. Praha: Sociologické nakladatelství.

- Berger, P. L., Luckamnn, T., (1999). Sociální konstrukce reality: Pojednání o sociologii vědění. Brno: Centrum pro studium demokracie a kultury.

- Biggs, M. (2009) Self-fulfilling prophecies. In The Oxford handbook of analytical sociology (pp. 294-314). Self-fulfilling prophecies.

10 Důležité je si uvědomit, že pracujeme v limitech lyotardovského pojetí metanarací, které pro popis současné společnosti již nemusí být aplikovatelné tak, jak je Lyotard použil na analýzu minulosti.

11 Transition Towns je sít měst zaměřujících se na to, jak se na mstní úrovni vyrovnat s klimatickou změnou a přicházejícím ropným zlomem. Více o Transition towns viz KLENOVSKÁ, Hana. Transition Towns ve Velké Británii: koncept a realita [online]. 2012. Diplomová práce. Masarykova univerzita, Fakulta sociálních studií. Vedoucí práce Naděžda Johanisová. Dostupné z: <http://is.muni.cz/th/103061/fss_m_a2/>. 
- Bruntland, G. H. et al., (1987). Report of the World Commission on Environment and Development: Our Common Future. . Retrieved from http://www.undocuments.net/wced-ocf.htm

- Future of Europe, Special Eurobarometer 379 (2012). Brussels: Evropská komise. Retrieved from http://ec.europa.eu/public opinion/archives/ebs/ebs 379 en.pdf

- Funda, O. A. (2000). Znavená Evropa umírá. Praha: Karolinum.

- Giddens, A. (2003). Důsledky modernity. Praha: Sociologické nakladatelství.

- Godemann (Jasmin), , \& Michelsen (Gerd), (2011). Sustainability communication: Interdisciplinary perspectives and theoretical foundations. Dordrecht: Springer.

- Lyotard, J. (1993). O postmodernismu: Postmoderno vysvětlované dětem: postmoderní situace. Praha: Filozofický ústav AV ČR.

- Merton, R. K. (1948). The Self-Fulfilling Prophecy. The Antioch Review, 8(2), 193210.

- Osn, (1992). Agenda 21. : OSN. Retrieved from http://www.un.org/esa/dsd/agenda21

- Osn, (2002). Johanesburg Plan of Implementation. : OSN. Retrieved from http://www.un.org/esa/sustdev/documents/WSSD POI PD/English/POIToc.htm

- Osn, (2012). The Future That We Want. : OSN. Retrieved from http://www.uncsd2012.org/content/documents/727The\%20Future\%20We\%20Wa nt\%2019\%20June \%201230pm.pdf

- Popper, K. R. (1957). The poverty of historicism. London: Routledge.

- ROSENTHAL Robert a JACOBSON, , \& Lenore, (1968). Pygmalion in the classroom, The Urban Review. The Urban Review, 3(1), 16-20. Retrieved from http://link.springer.com/10.1007/BF02322211 http://dx.doi.org/10.1007/BF02322211

- Transition Towns. Principles (2012). . Retrieved from http://www.transitionnetwork.org/about/principles

- VAlÉRY (Paul), , \& HYTIER (Jean), (2000). . Paris: Gallimard.

\section{Autoři:}

Mgr. Jan Labohý,

Student doktorského studijního programu Sociologie, oboru Humanitní environmentalistika, na Fakultě sociální studií Masarykovy Univerzity. Zaměřuje se na problematiku vnímání budoucnosti. Kontakt: labohy@mail.muni.cz

Mgr. Bohuslav Binka, Ph. D. 
Vedoucí katedry Environmentální studií Fakulty sociální studií Masarykovy Univerzity. Věnuje se zejména oblasti environmentální etiky.

Kontakt: binka@fss.muni.cz 
Časopis Envigogika vydává Centrum pro otázky životního prostředí UK. Vývoj časopisu je podpořen projektem OP VK Mezioborová sít udržitelného rozvoje.

Více najdete na internetových stránkách projektu http://mosur.czp.cuni.cz
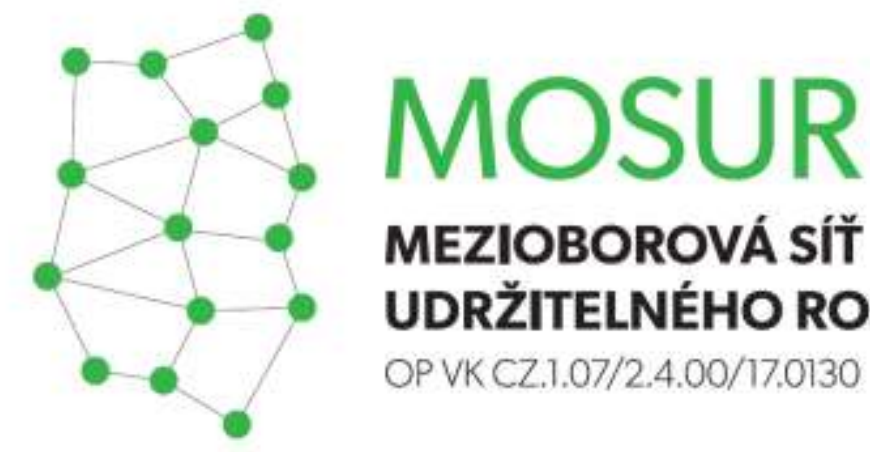

\section{MEZIOBOROVÁ SÍT}

UDRŽITELNÉHO ROZVOJE

OP VK CZ.1.07/2.4.00/17.0130

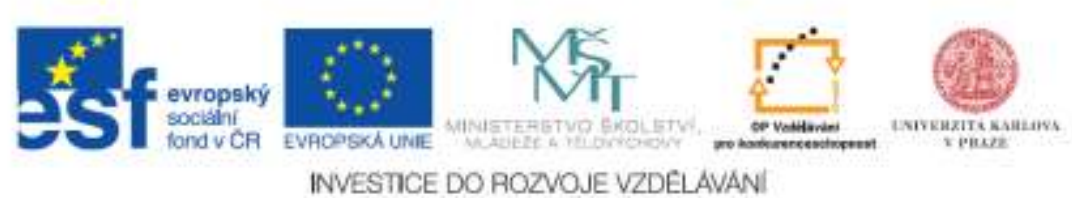

INVESTICE DO ROZVOJE VZDELAVANI 